\title{
Ecology and structural violence: The South African reception of Lutheran voices from North America
}

NGTT DEEL 55, NR 3 \& 4, 2014

\section{Conradie, Ernst M}

University of the Western Cape

\begin{abstract}
This review essay offers an assessment of two recent monographs by Larry Rasmussen and Cynthia Moe-Lobeda in the field of ecotheology. It focuses on the category of moral vision that both authors employ. It shows how the notion of critical moral vision helps to identify and assess the root causes of economic inequalities and ecological destruction in terms of structural violence, structural evil and the very nature of sin. It also explains why such moral vision forms the key but by itself remains insufficient for social transformation. The influence of such insights in the South African context is illustrated with reference to teaching and research done at the University of the Western Cape and, more specifically, the category of transfiguration in Desmond Tutu's theology.
\end{abstract}

\section{KEYWORDS}

Ecotheology, Cynthia Moe-Lobeda, Moral vision, Larry Rasmussen, Sin, Structural violence, Transfiguration, Desmond Tutu, University of the Western Cape

\section{CONTACT DETAILS}

Ernst M Conradie

Department of Religion and Theology, Systematic Theology and Ethics

University of the Western Cape

econradie@uwc.ac.za 


\section{INTRODUCTION}

In 2013 renowned North American Lutheran ethicists in the field of ecotheology published two substantial monographs. Larry Rasmussen's latest monograph entitled Earth Honoring Faith: Religious Ethics in a New Key (461 pp), was published by Oxford University Press, while Cynthia Moe-Lobeda's Resisting Structural Evil: Love as Ecological-Economic Vocation (306 pp) was published by Fortress Press. Rasmussen is the emeritus Reinhold Niebuhr Professor at Union Theological Seminar in New York while Moe-Lobeda (Rasmussen's former student) is Wismer Professor of Gender and Diversity Studies at Seattle University.

As may be expected, there are several similarities between the two texts. Perhaps the crucial aspect is the mapping of moral categories that Rasmussen developed in earlier contributions and that Moe-Lobeda takes over and develops further from her mentor (who also wrote the foreword for her book). In both cases a central place is given to the emergence of a moral vision. I will return to this in the discussion below. Both come from the Lutheran tradition and from a school of Christian ethics influenced by Dietrich Bonhoeffer. Both write from within the North American context and engage critically with (mainly) North American readers. Both texts are particularly well written. Rasmussen's style is evocative and at times poetic. MoeLobeda writes in a prophetic mode, interspersed with social analysis, theological commentary and a narrative mode of moral discourse indicative of what she describes. There is a welcome sensitivity to religious plurality in both texts although Rasmussen draws far more extensively on non-Christian tradition than MoeLobeda does. Given her targeted readers she emphasises the unique burden and responsibility of Christianity in North America (2013:8).

In this review essay I will focus on the category of the emergence of a moral vision that both authors emphasise. I will show how the notion of critical moral vision helps to identify and assess the root causes of economic inequalities and ecological destruction in terms of structural violence, structural evil and the very nature of sin. Such a moral vision also forms the key but by itself remains insufficient for social transformation. The influence of such insights in the South African context will be illustrated with reference to teaching and research done at the University of the

Western Cape and, more specifically, the category of transfiguration in Desmond Tutu's theology.

\section{RASMUSSEN ON AN EARTH HONORING FAITH}

In his earlier work Rasmussen (1972/2005) engaged extensively with Dietrich Bonhoeffer's Christian ethics. He learned from Bonhoeffer an emphasis on the role 
of community, the need for moral formation in moral communities and to maintain ecumenical networks. He expressed a deep concern over the fragmentation of such moral communities in Moral Fragments, Moral Community (1983). He also learned from Bonhoeffer the need to relate such an emphasis on moral community to contextual challenges. For Bonhoeffer, this was shaped by the need for communities of resistance in the context of anti-Semitism. For Rasmussen, the context is increasingly shaped by the environmental impact of neo-liberal globalisation. In The Predicament of the Prosperous (1978) that he co-authored with Bruce Birch he already described the impact of consumerism on moral communities. In Earth Community, Earth Ethics (1996) he then developed the notion of "sustainable community" as an alternative ecumenical vision amidst social, economic and ecological disintegration. This is also a dominant theme in Ethics for a Small Planet (1998), which he coauthored with Dan Maguire. Drawing on the ecumenical root metaphor of the whole household of God, he pointed to the etymological roots of the English words economy, ecology and ecumenical in the Greek oikos (household). He rooted this notion of household in the so-called "great economy", namely the underlying structure of the earth's ecosystems - which constitutes an "earth community".

All these themes come together and are developed further in Earth Honoring Faith, which may well constitute Rasmussen's magnum opus. The book is structured in two parts. In the first part there are chapters on the kind of "creatures we are" and the "world we have", drawing insights mainly from other disciplines. In a chapter on "The faith we seek" he argues that any response to ecological destruction from within religious communities have to be deeply rooted in the symbols of a particular tradition. While he draws throughout the book on sources in other religious traditions, this clearly also applies to Christianity. In four chapters he then develops "the ethic we need". He develops a map of moral categories (2013:127-159) in which the role of goals, values, duties (also principles and rules) and virtues are integrated with one another on the basis of the crucial role played by moral vision (and moral imagination). He comments that moral vision is powerful and moves multitudes, albeit often slowly (2013:147). It provides the basic storyline for the morality we live by (2013:145). He adds that: "Moral vision and moral narrative may change, and do. But then the story changes, as do the optics, and a different life is lived" (2013:145). The specific vision that Rasmussen has in mind is that of the world as oikos, that is, of economics, ecology and ecumenics as interrelated dimensions of the same world (2013:148). This requires a notion of eco-justice (see 2013:150-159) where economic growth and high levels of consumption are no longer the main markers of well-being. 
On its own moral vision would of course not suffice. Behavioural change often precedes attitudinal change (2013:119). Rasmussen therefore describes the "dialectic of change" in anticipatory communities in terms of four "notes": 1) For deep change to happen, the drag of normalcy must be resisted and conventional wisdom doubted; 2) Leadership and the first initiatives for major change, including perspectival change usually come from minority communities at the edges or bottom of society; 3) While almost every change movement is begun by the dreamers, it fails if influential allies in privileged circles are not forthcoming; and 4) Change that addresses today's wicked problems for the sake of new first works requires that we understand complex adaptive systems (2013:121-124). Such insights are then developed further in chapters on the role of moral community within the context of civil society (2013:160-190) and sustainable earthkeeping practices amidst the quest for environmental justice (2013:191) - a chapter that could also have been moved to the latter half of the book.

In the second part of the book Rasmussen develops selected themes further in order to outline an alternative moral vision. He explores an appreciation for asceticism amidst consumerism (also with reference to the Eucharist), for the sacred amidst commodification, (with reference to debates on water) for prophetic liberative practices amidst oppression and for wisdom amidst folly. These chapters show a master at work, one who can attend to the detail required in local contexts but who maintains a cosmic vision throughout.

I want to focus here on a specific aspect of Rasmussen's argument, namely the diagnosis of the underlying problem. Following observations from Daniel Quinn's text Ishmael Rasmussen raises the question why we don't just stop when we know that we are destroying the world around us (2013:89). Why do the injuries of nature delight us (2013:89)? He considers various answers: a lack of compassion, a reductionist utilitarian logic, a managerial anthropocentrism, ignorance of the consequences, human arrogance as a self-segregated species, turned in upon itself (cor curvatum in se), setting itself apart from the community of life, the abuse of power and privilege together with the inequalities and injustices that flow from power imbalances as a result of greed (the will to power), and pervasive ideologies. It is indeed remarkable how fruitful the traditional Christian vocabulary on the nature of sin has proved to be in order to identify the root causes of environmental destruction (see Cloete 2013). Sin is at once manifested in anthropocentrism (pride), consumerism (greed), a lack of development (sloth), domination in the name of difference (violence) and human alienation from the rest nature (the privation of the good - see Rasmussen 2013:209). It may be necessary to acknowledge that language 
about original sin obscures more than what it reveals (2013:99), but there can be no doubt about persistence of what Rasmussen calls "pervasive perversity" (2013:100).

Rasmussen then offers a constructive contribution on the basis of a rereading of the ethic of masters and slaves. He describes the Earth / human relationship as one of subject-over-object and mind-over nature that yields a "paradigm of domination that renders nature essentially a slave to humanity, its steward and master" (2013:100). He criticises a stewardship ethic on this basis, reminding us that white Christian slaveowners considered themselves to be good stewards of slaves. The rest of nature has become enslaved to serve human purposes. Rasmussen adds: "Slaves are certainly not dispensable. But they are replaceable; one can substitute for another. This is the master/slave ethic in pure form" (2013:100). He adds that it is unnerving to realise how "natural" this relationship has remained for self-appointed stewards of nature given how stewardship mimics the relationship between master and slave and even though slavery is no longer permitted.

Rasmussen is very much aware of how such a master / slave dialectic becomes embedded in the structures of society. He labels this "structural sin", a theme developed more fully by Moe-Lobeda. He observes that the prophetic imagination has a keen sensitivity for institutionalised practices, the habits by which we live. He says: "The practices of systems and structures are the true judges of how we're doing. Ideological claims, creeds, beliefs, rituals, and the noise of solemn assemblies pale alongside routine practice as the measure of our lives" (Rasmussen 2013:306). He adds provocatively: "Tell us your income and your zip code and we will tell you how you live and the world it creates. We'll describe your education, diet, energy use and transportation. We'll describe the housing you have, the company you keep, the way you spend your leisure time, and how you treat your neighbours and the world" (2013:306). This, he also observes, applies irrespective of religious persuasions. Such structures of domination call for prophetic critique - and leads Rasmussen to a discussion of Dietrich Bonhoeffer, Martin Luther King Jr. and Mohandas Ghandi.

Moe-Lobeda suggests that more than prophetic critique is necessary in order to address structural violence. Rasmussen would concur. He calls for an interplay between prophetic-liberative traditions and the moral formation in anticipatory communities. Prophets attend to institutional justice better than virtue traditions and recognise that behavioural change may well precede attitudinal change. However, it cannot be assumed that virtue will always finds its way: "Prophetic traditions are, however, oftentimes impatient with the long, slow schooling of the very character and conscience they cannot do without. They organize union members and college students but not preschoolers" (Rasmussen 2013:363). 
What is needed is both ongoing moral formation and the institutional scaffolding of a just way of life (2013:363). The source of inspiration for that, Rasmussen believes, will best come from "sacred strangers in secular society, embedded in deeply rooted faith traditions, who can recast older insights into new patterns that can address adaptive challenges of the day (2013:364). This is the making of the moral vision for an emerging order. This requires focal practices in deeply rooted, shared traditions, a life of discipleship, an appreciation of the various "stations" on a journey (or pilgrimage) of faith, with some cairns along the way, and the practising of arcane disciplines (Bonhoeffer) (2013:232-235).

\section{MOE-LOBEDA ON RESISTING STRUCTURAL EVIL}

In response to the question as to why we don't just stop when we realise we are destroying what is precious, Rasmussen acknowledges that most people, including most rich people, don't want to destroy the world (Rasmussen 2013:94). It is not malice that is the problem. This is the point of departure for Cynthia Moe-Lobeda's analysis of structural evil. She addresses her book specifically and quite narrowly to North Americans who are "overconsumers" (2013:5) and economically "privileged" (2013:11). They regard themselves as compassionate and well-intentioned citizens but their ways of living are embedded in economic structures that are causing gross economic inequalities as well as ecological destruction (2013:31-45). As a result, structures of exploitation persist but those who benefit from such structures fail to recognise and resist them (2013:4). She asks provocatively: "What does it mean for us, killers, to claim moral lives?" (2013:4).

The answer for Moe-Lobeda lies in an analysis of structural violence (a sociological concept derived from the peace research of Johann Galtung) that she re-describes as "structural evil" (a theological concept) (2013:49). Structural violence refers to the physical, psychological and spiritual harm that some experience as a result of an unequal distribution of power but also to the complicity and acquiescence of those who benefit from that (2013:72). While direct violence is an event, structural violence is embedded in structures and processes (2013:75). The prime examples of such structural violence are the ideologies of racism, classism and sexism but it also becomes evident in the build-up of weapons and anthropogenic climate change, more specifically climate debt (2013:59).

Moe-Lobeda acknowledges notions of sin as ignorance, greed and arrogance and emphasise the role of violence ("crucifying Earth" - 2013:56), but the main gist of her argument is to focus on what has traditionally been called sin as power, i.e. the way in which whole societies become collectively trapped in structures that are violent. In other words: while Rasmussen seeks to explain the root causes of 
structural evil in terms of the very nature of sin, Moe-Lobeda emphasises the consequences of sin with specific reference to structural evil. For Moe-Lobeda sin is not merely wrongdoing (through attitudes, thoughts, words or deeds) but a state of disorientation where people have become curved in upon themselves (2013:58). Her argument is not merely that sin becomes embedded in structural forms, but that the implications of that for the practice of faith remain largely unacknowledged (2013:58). She identifies four features of structural evil, namely its invisibility to those who do not suffer directly from that (breeding complicity), the fact that it is sustained irrespective of the virtue or vice of people involved, its transmission from one generation to the next unless exposed, confronted and resisted, and its expansion as a result of the concentration of power, for example in the case of neoliberal globalisation (2013:60-64).

How is it possible that virtuous people (who in their self-understanding seek to live moral lives) can support an evil system (a question also discussed with reference to apartheid South Africa)? How is such moral oblivion and the abdication of moral power possible? How can evil appear to be disguised as light (Bonhoeffer) (2013:66)? How does structural evil manage to remain hidden beyond recognition for its perpetrators and beneficiaries? Drawing on Antonio Gramsci and Cornel West, Moe-Lobeda argues that this is possible as a result of hegemonic vision (2013:86). This hides the truth both from perpetrators and victims of evil systems. In this way people can come to consent to social systems (even slavery, colonial rule and domestic violence) through which they are oppressed and exploited. In an excellent analysis she identifies eight factors contributing to hegemonic vision amongst her primary readers, namely well-intentioned, compassionate over-consumers in North America who live in ways that are based on systems of structural violence that impoverish others and cause ecological destruction. These are 1) a privatised morality based on charity, 2) gratitude for the many "blessings" received from God, 3) denial through self-justification, 4) a sense of hopelessness and perceived powerlessness given the "inevitability" of current systems, 5) unconscious conformity to social pressures, for example through advertising, 6) corporate investment in maintaining moral oblivion through public relations exercises, 7) the assumption that economic growth is necessary, and 8) moral oblivion, that is, practiced denial in the name of powerlessness (2013:88-104).

Drawing on Rasmussen's work, Moe-Lobeda concurs that hegemonic vision is best countered through the emergence of a critical moral vision. She takes the argument forward by suggesting that moral vision has several distinct dimensions that include seeing what is, what has gone wrong and what is not yet there but ought to be. Seeing and judging are therefore co-original. This point is not always recognised in the widely 
used see-judge-act method. If social analysis necessarily precedes discernment, then social analysis may easily determine the content of theological reflection. It is not possible to see what is wrong without seeing what ought to be - precisely because evil can become disguised and hidden from the consciousness of perpetrators and through false consciousness even from victims. Evil can be portrayed in multiple ways as normal, obvious, necessary and therefore as somehow acceptable, if not always hidden. It can even be paraded as fate, divinely mandated, or as punishment for $\sin 2013: 66-68)$. The evil embedded in structural violence shows a tendency to hide itself through selective morality and especially selective justice. Evil that is not recognised for what it is cannot be addressed and resisted (2013:258). It can only be seen when the possibility of alternatives is recognised.

On this basis Moe-Lobeda outlines three dimensions of a moral vision: a clearer vision of economic and ecological injustices, a vision of sustainable alternatives and the moral power to embraces these alternatives (see 2013:5, 112, 299). The last of these is elicited by "mystical seeing, i.e. "seeing ever more fully the life-giving, life-saving Mystery that is God flowing and pouring through all of creation, and working there toward creation's suffering" (2013:299). Here she builds on the mystic vision of an indwelling God developed in her earlier work Healing a Broken World (2002:73-99) that also called for a subversive moral agency. This mystical vision is one of seeing the world through the eyes of God. She says: "To see oneself through the eyes of God, to see what God sees, is to see a human creature loved beyond comprehension" (2013:140). She adds: "To see others through the eyes of God is to see them first and foremost as precious beloved creatures of God" (2013:140). This enables her to see God as "flowing and pouring through all things" (2013:140144). She acknowledges God's transcendence but stresses God's immanent presence as guiding, empowering and equipping (2013:142). On this basis she affirms God's love for (human) creatures as liberating in that it overcomes alienation (sin) and enables justice-making love for God, others and the Earth (2013:145). She develops this mystical vision in a Trinitarian way and suggests that this opens a "horizon of hope" that evil is ultimately overcome by the power of God's love (2013:153). Her intuition is that moral inertia is born from a lack of hope that structural violence can be overcome (2013:153).

In the second half of the book Moe-Lobeda explains how the "seeds of hope" elicited by such a mystical vision may be translated despite the pernicious presence of evil towards love as economic-ecological vocation (the sub-title of her book). Thus a mystical vision accompanies a critical moral vision. On this basis she describes some ten features of love as a theological norm (2013:167-173). There is no need to describe this analysis except to comment that love is understood here as a disposition 
and not primarily as the quality of a relationship (which would have correlated with her notion of sin as a situation of alienation rather than as the disposition, thought, word or actions of an individual). This notion of love is developed further in relation to the concept of social justice in critical altercation with Reinhold Niebuhr's views in this regard (2013:176-185, see also Rasmussen 2013:94-98). She then explains how neighbourly love as economic-ecological vocation implies compassion and justice (2013:199), but also the "triple bottom line" of ecological sustainability (2013:201-204), environmental equity in response to ecological debt (2013:207-211) and economic equity given the social impact of the globalised neo-liberal economic order and the undermining of democracy (2013: 214-217).

For Moe-Lobeda the task of Christian ethics is to provide a layout of the path from moral vision to emancipatory praxis in order to enable us to follow this path. Like Larry Rasmussen (again her mentor in this regard) she recognises that a changed moral vision affects all other elements of the moral life (Moe-Lobeda 2013:245), but does not suffice on its own. She agrees that moral vision entails both a critical and an inspiring dimension and adds that an emerging moral vision also changes one's perception of what is possible, not only of what is wrong and of what should be (2013:246). Such a vision may be taken forward by identifying its defining features in terms of moral principles. For her these have to include ecological sustainability, environmental equity, economic equity and democracy (2013:247). Such principles require the formulation of goals or middle axioms in order to help us imagine how the vision will be realised, that is, what the first necessary steps may be on this path (2013:247-249). These goals still have to be translated in policies and a range of practices in order to realise such goals (2013:249-253). These have equal weight as transformed practices may affect policy changes while new policies will also induce appropriate practices (2013:253-255). Like Rasmussen, she recognises the key role of moral formation (the elephant in the room of social change - 2013:257). Again like Rasmussen, she recognises the danger of malformation and that communities can be patriarchal, restrictive and oppressive. The prime example of the practices that are required remains that of worship - through which we learn to see the world through God's eyes (2013:259-260). The liturgy is a "school for seeing" (2013:263), for entertaining a different way of looking at the world. Where this does not happen, where worship services merely reflect the divisions in society (especially of class and race), such worship has already become idolatrous. This raises the question how affluent Christian communities in the global North can celebrate the Holy Communion, yet continue with patterns of life that induce suffering to others and that destroy ecosystems (2013:259). If Sunday 10h00 remains the "most segregated 
hour", this is a question that also plagues South African church life (see Van der Borght 2009).

Moe-Lobeda cannot answer this question, but that may well be the real question that she raises to her students and her readers in North America. Instead, she entices them to put love as justice into action. She concludes her book by describing eight "gateways" for resistance and rebuilding. This forms a crucial part of her argument in helping her readers to imagine the first necessary steps that may be required to bring about an alternative vision. These gateways include small-scale local and regional alternatives, fostering a moral culture in institutions, voluntary corporate social responsibility, publically mandated constraints, revoking the notion of "corporate personhood", and prohibiting unwanted corporations through consumer action (Moe-Lobeda 2013:278-292). Again, these are neatly illustrated with life stories that can help readers to imagine how such gateways may be employed in their own local contexts.

\section{THE CATEGORY OF MORAL VISION: DESMOND TUTU ON TRANSFIGURATION AND TRANSFORMATION}

Both Rasmussen and Moe-Lobeda hold that an attractive moral vision provides the source of inspiration for moral action, for embracing the envisioned alternatives, for resisting evil, even for overcoming structural evil. A critical moral vision provides the source of energy for communities and organisations to become dynamos for social transformation.

This emphasis on moral vision, already developed in the map of the moral landscape in Birch and Rasmussen's Bible \& Ethics in the Christian Life (first edition 1976), has been very influential at the University of the Western Cape where I teach. In 2000 we introduced a subject simply called "Ethics" that explores the "moral and religious foundations of society". The subject may be taken as a major towards an undergraduate degree in Arts, Psychology or Theology. Student numbers have grown remarkably to reach around 700 first year students, 200 second year students and 150 third year students in 2014 .

The curriculum draws on philosophy but also on religious studies in order to help students to understand the dynamics of moral formation taking place in local communities, civil organisations and faith communities in South Africa. The emphasis is on a form of virtue ethics that recognises the need for responsible citizenship and not only personal virtue. Morality is therefore not reduced to dilemmas in moral decision making encountered in situations that are interesting but that our students would hardly ever come across. Ethical theory is not reduced 
to debates on deontological and utilitarian approaches - although these are certainly addressed if only extensively at the third year level. Instead, explicitly following the examples in Birch and Rasmussen (1989), students are introduced to a map of the moral landscape that is developed in terms of the categories of a moral vision for the good society, the need for the formation of virtue towards responsible citizenship and then the need for understanding the role of values (also goals) and obligations (also rules) in moral decision making. The key here is to prioritise questions about the good society and to recognise the significance of an alternative moral vision. Indeed, the struggle against apartheid in South Africa was at its core a struggle for an alternative vision, namely a vision for a non-racist, non-sexist democracy in a unitary state. This is developed in a co-taught course entitled "A first introduction to ethical theory" that forms the theoretical foundation for the subject (see Conradie et al 2006).

This teaching programme is coupled with a current research project on the interplay between ecumenical theology and social ethics. The question behind this project is elicited by the "and" that links the two themes. There can be no doubt that religion plays a crucial role in social transformation, but also that religion can play a destructive and not only a constructive role. It can be used both to reinforce patriarchy and to resist violence against women and children. It can elicit reform but also deform movements (see Conradie \& Pillay 2015). The moral power that can sustain social transformation in the face of many obstacles is clearly attractive in the public sphere, also in the corporate world. It is often assumed that the "moral capital" on which societies depend, is typically cultivated in religious communities. However, leaders in faith communities also recognise that a moral vision does not always lead to appropriate forms of praxis. Indeed, as Rasmussen repeatedly recognises, changed perceptions often follow behavioural change. Such behavioural change may be induced by a range of other factors that may well be beyond the sphere of influence of religious communities. This begs further questions about the interface between moral vision and moral praxis. This is where the two books by Rasmussen and Moe-Lobeda are so significant since they address this question head-on, albeit from within a quite different context.

At UWC this question is raised with specific reference to Desmond Tutu, the longstanding former Chancellor of the university. A Desmond Tutu Chair of Ecumenical theology and Social Transformation in Africa has been established in the Department of Religion that has now also been coupled with a Desmond Tutu Centre for Spirituality and Society. In each case there is an "and" that invites further reflection. At the core of understanding this "and" lie ecumenical efforts to reflect on "ecclesiology and ethics" (see Best \& Robra 1997), that is, on the relationship between what the 
church is and what the church does. Rasmussen's hand is distinctly visible in such ecumenical discourse on ecclesiology and ethics (see Rasmussen 1997). This tension between ecclesiology and ethics is related to other well-known theological tensions, for example, between the indicative of God's grace and the imperative of God's will, between liturgy and life, between the liberating message of God's forgiveness, and the liberative praxis that follows from that, between justification and sanctification, between a compelling vision and moral discernment, and between dogmatics and ethics.

In the UWC project on ecumenical theology and social ethics it is often said in jest that Desmond Tutu somehow seems to have fathomed the relationship between spirituality and society because he tends to talk politics when he speaks as a church leader and starts praying when he engages in politics. Further investigation of Tutu's oeuvre confirms that the key to keep the tension alive is for him a moral vision, a particular way of seeing the world. This is expressed in his ubuntu theology through the notion that we are all members of God's family. It is perhaps best expressed in a small but significant book entitled God has a Dream (2005) in which key to Tutu's theology may well be found. In this book he consistently employs the metaphor of God's family. He observes that it makes a huge difference to see a beggar as your brother, a prostitute as your sister and a perpetrator of gross violations of human rights as your uncle. Tutu (2005:97) comments: "People really are wonderful. This does not mean that people cannot be awful and do real evil. They can. Yet as you begin to see with the eyes of God, you start to realize that people's anger and hatred and cruelty come from their own pain and suffering. As we begin to see their words and behaviour as simply the acting out of their suffering, we can have compassion for them." Tutu explains that by calling God Abba (our Father) we accept our oppressors and enemies as our brothers and sisters. They belong together with us in the family of God so that their humanity is caught up in our humanity just as ours is caught up in theirs (see Battle 1997:47). Tutu (2005:23) then explains the moral implications of such a vision:

In a happy family you don't receive in proportion to your input. You receive in relation to your needs, the ones who make the least material contribution often being the ones who are most cared for - the young and the aged.

How I pray that in our world we can learn to emulate a true family. Perhaps then we could address the injustices that cause a small percentage of our world to consume the vast majority of its resources - not unlike what happened under apartheid in South Africa - while the vast majority lives in poverty, with over a billion people living on less than a dollar a day. Would you let your brother's or sister's family, your relatives eke out a miserably 
existence in poverty? Would you let them go hungry? ... If we realized that we are family, we would not let this happen to our brothers and sisters.

What conditions are required to allow for the emergence of such a moral vision? For Tutu, the key lies in an awareness of the presence of God through the Word and the Spirit in our midst, especially in the context of suffering and especially amongst the victims, but also the perpetrators. From a reformed perspective I would add that seeing others as members of God's family does not come naturally and does not follow from a Gnostic form of insight amongst the educated elite only, but requires the inner illumination of the Holy Spirit. This ability to see the world through God's eyes has little to do with good eyesight or helpful spotlights but with discerning the loving presence of God in our midst. This does not provide new light like a limelight, but it warms the heart and allows the broken figure to glow with God's presence. One could say this works in the way that one would blush in the mere presence of one's very first love. The same applies to Tutu's own illustrious presence: When he is in a room this influences how people act and what they say- without him doing or saying anything!

For Tutu himself (as shaped by the Community of the Resurrection to which he belongs), this is best expressed in the biblical narratives on the transfiguration of Jesus on the mountain. There his face, clothes and body became radiant and translucent with the luminosity of God's presence (Tutu 2005:93). On the mountain Jesus, the rabbi from Nazareth, was revealed as more than an itinerant teacher and healer. The vision embedded in the experience of transfiguration enables us to see this Jesus from God's perspective. The moment when this vision is grasped also yields the temptation to become like God, to escape from the world, to ascend the mountain even further. If so, the experience of transfiguration would become an aim in itself. This is corrected by the recognition that it is this human (Jesus) who is seen in a new light. The experience of seeing God is not an aim in itself but is always already a way of seeing this world through God's eyes.

On this basis, in being sent down the mountain, we can also see other broken bodies from God's perspective. As Desmond Tutu (2005:96) adds: "The divine shines through material that was thoroughly unpromising, unlikely, improbable." Christological transfiguration is therefore inextricably linked with pneumatological transformation. This creative tension between transfiguration and transformation is epitomised in Tutu's own ministry. It is a particular spiritual vision that elicits, inspires and sustains his social activism. The symbol of transfiguration lies at the very core of his spiritual vision. While this may have harboured the dangers of disconnection or escapism - as if the human being is supposed to become divine, this is evidently not Tutu's understanding. Instead, the experiences of transfiguration enables one 
too see both the oppressed and the oppressor as children of God, belonging to God's own family, the household of God. Once this vision is entertained, the implications for social transformation become obvious. For Tutu, transfiguration cannot but lead to spiritual and social transformation. A lack of transformation would simply imply that the world has not yet been seen through God's eyes. When one is then confronted with social problems where the world is viewed according to a very different and rather relentless capitalist or consumerist logic, this drives Tutu back on a daily basis to draw inspiration from his particular form of spirituality.

\section{CONCLUSION: RESISTING STRUCTURAL EVIL}

It needs to be acknowledged that there is another side to the story. It may be true that the imperative of God's will becomes possible on the basis of the indicative of God's grace. However, beliefs do not always shape values and praxis. There is a gap between what we believe (or think we believe) and what we know we ought to do but find ourselves somehow unable to do. What we confess to believe is not necessarily that which we put our trust in. There is all too often a tension between orthodoxy and orthopraxy, between our "ecclesiology" and our "ethics". In a way this is intolerable: once one sees the world through God's eyes, it cannot but transform one's attitudes, actions and habits. But it is also true that vision is not enough. Perhaps moral inertia in the face of ecological destruction is not the result of the failure to see what is happening but the lack of hope that things can change (Moe-Lobeda 2013:153). It seems that faith and hope can be in tension with each other even though this is theologically indefensible. Reform movements are not always sustained. Worse: they may become distorted as deform movements.

In my view the two monographs by Rasmussen and Moe-Lobeda takes the debate in ecotheology forward on this very point without undermining the central role of moral vision. They realise that "acting" without "seeing" and "judging" is dangerous. This requires what Moe-Lobeda terms a "critical moral vision". It requires a detailed social analysis of the current global economic order and its impact on socio-economic inequalities and ecological destruction. Moreover, it requires an understanding of the nature of structural violence. She does not elaborate on the subsequent "spiral of violence" (widely used in theologies of liberation) where structural violence prompts revolutionary violence, only to be followed by repressive violence. Her discussion of hegemony (2013:86f) is at least a helpful step in that direction. The narratives that she includes also hint at the obstacles to resistance and the repression of such resistance to defend corporate interests.

Moe-Lobeda also realises that a description of structural violence remains insufficient if not complemented by a theological "judging" of such violence in 
terms of the notion of structural evil. She realises that more needs to be said about the relationship between structural evil, natural evil and metaphysical evil (the condition of finitude) (see 2013:64), but does not tackle this thorny problem. She hints at the dialectic between sin and evil where evil is regarded as the cumulative impact of sin - where collective wrongdoing has become embedded in the structures of society in such a way that humans have become trapped in a situation from which they cannot escape. She offers some discussion on the nature of $\sin (2013: 58)$ but her main aim it to explore the structural dimension of evil. In this way she complements Rasmussen's excellent discussion of the very nature of sin - which in my view is unsurpassed in Christian ecotheology.

It seems to me what is needed here is a more sophisticated theological understanding of the notion of human sin, both as power and as guilt - one that resists an easy classification of humanity into perpetrators and their innocent victims (on the one hand) and an equally easy universalising assessment that we are all sinners before God (on the other). Any distinctions can become inverted: victims may victimise others (illustrated by gangsters), while perpetrators may be transformed by the grace of forgiveness. As the South African Truth and Reconciliation Commission helped us to see, there are also willing and unwilling beneficiaries and some bystanders and spectators who are not always so innocent (see also Moe-Lobeda's mentioning of active thieves, passive profiteers and deprived victims - 2013:57). It may be true that we are all victims of structural violence and have all contributed to it, but the responsibility and the burdens are not equally distributed so that there may be a need to speak about the proportionality of guilt (see Conradie 2013:45-52). Those who are perpetrators of one form of structural violence may be victims of another form (see Moe-Lobeda 2013:74). Perpetrators of violence and those who benefit from structural violence themselves eventually become victims of the system. Those who are in prison may be free (Nelson Mandela comes to mind), while those in positions of immense power may be held captive by their ideologies and suffer psychologically from that.

This focus on evil as rooted in human sin is crucial in order to recognise the roots of environmental destruction. Accordingly, the core of the problem does not lie with God, God's creation, nature, evolution, vulnerability, and anxiety or with the human species as such. The only (!) problem is human sin - which is something contingent that can and in Christ has indeed been resolved. This liberating view on human sin as the root of the problem may seem to be too good to be true given the immensity of the powers that rule the global economy and the scale of destruction. The emphasis on the confession of sin is therefore resisted in many cultural contexts. 
It has been far from easy to maintain such a focus on sin as the primary problem once questions around the origin of sin (including the notion of original sin) are explored. Where does sin come from? From evil, but where does evil come from? From the devil, but where does the devil come from? From God? The classic Christian position is that sin is finally inexplicable and that, if anything, humanity as a whole is to be blamed. However, the temptation to explain sin does not go away easily. Sin may, for example, be "explained" with reference to the struggle for the survival of the fittest (the "selfish gene") or human anxiety over finitude. The focus thus shifts to the underlying structures of being embodied, especially to vulnerability, mortality, transience and the limitations of human power and knowledge. If so, God's good creation becomes part of the problem. This has to be a concern for any adequate ecotheology.

In contemporary theology this line of thinking typically begs further questions around natural suffering and natural evil. Would an emphasis on human sin not underestimate the problem of natural suffering? Can all forms of suffering really be derived from human sin? What other sources of suffering may be identified? Has something gone wrong with the evolution of life on earth, irrespective of the emergence of the human species? Is there a sense in which nature too has to be redeemed (irrespective of human impact), for example with reference to the violence and brutality that characterise relationships between non-human animals? What exactly is the problem from which the earth has to be saved?

This set of problems clearly requires further investigation. At UWC we hope to investigate this theme in more depth in a future project on "Redeeming sin: Hamartology, ecology and social analysis" in which the question will be how a Christian confession of sin can be retrieved and portrayed as good news for the whole earth (see also Cloete 2013, Conradie 2005, Conradie \& Sakuba 2006).

The core strength of the two monographs does not only lie in the emphasis on moral vision or on social analysis ("seeing"). Both Rasmussen and Moe-Lobeda realise that "seeing" and "judging" need to be followed by "acting". They realise the central problem of Christian ethics, namely that knowing God's will does not necessarily lead to doing God's will. They therefore analyse the obstacles in this regard and indicate what acting entails in order to resist the dominant powers and to rebuild sustainable communities. These are most welcome contributions to global ecumenical discourse and clearly take the debate in ecotheology forward on this point. 


\section{BIBLIOGRAPHY}

Best, Thomas F \& Robra, Martin (eds) 1997. Ecclesiology and ethics: Ecumenical ethical engagement, moral formation and the nature of the church. Geneva: World Council of Churches.

Birch, Bruce C \& Rasmussen, Larry L 1989. Bible \& Ethics in the Christian Life. Minneapolis: Augsburg Press.

Birch, Bruce C \& Rasmussen, Larry L 1978. The predicament of the prosperous. Philadelphia: The Westminster Press.

Cloete, Newton M 2014. Hamartology and ecology: A critical assessment of Dietrich Bonhoeffer's view on the nature of sin. M.Th. mini-thesis. University of the Western Cape.

Conradie, Ernst M 2005. Towards an ecological reformulation of the Christian doctrine of sin. Journal of Theology for Southern Africa 122, 4-22.

Conradie, Ernst M 2006. Morality as a Way of Life: A first introduction to Ethical Theory. Stellenbosch: SUN Press.

Conradie, Ernst M (ed.) 2013. Reconciliation as a Guiding Vision for South Africa? Stellenbosch: SUN Press.

Conradie, Ernst M \& Pillay, Miranda N (eds.). 2015. Ecclesial reform and deform movements. Stellenbosch: SUN Press (forthcoming).

Conradie, Ernst M \& Sakuba, Xolani S 2006. Sin and evil in African Christian theologies: A classification. Ned Geref Teologiese Tydskrif 47:1\&2, 60-73.

Maguire, Daniel \& Rasmussen, Larry 1998. Ethics for a small planet: New horizons on population, consumption, and ecology. Albany: State University of New York Press.

Moe-Lobeda, Cynthia D 2002. Healing a Broken World: Globalization and God. Minneapolis: Augsburg Fortress.

Moe-Lobeda, Cynthia D 2013. Resisting Structural Evil: Love as EcologicalEconomic Vocation. Minneapolis: Fortress Press.

Rasmussen, Larry L 1972. Dietrich Bonhoeffer: Reality and resistance. Abingdon. (2005 edition published by Westminster John Knox). 
Rasmussen, Larry L 1996. Earth Community, Earth Ethics. Maryknoll: Orbis Books.

Rasmussen, Larry L 1997. The right direction, but a longer journey. In: Best, Thomas F. \& Robra, Martin (eds.): Ecclesiology and ethics: Ecumenical ethical engagement, moral formation and the nature of the church, 105-111. Geneva: World Council of Churches.

Rasmussen, Larry L 2013. Earth Honoring Faith: Religious Ethics in a New Key. Oxford: Oxford University Press.

Rasmussen, Larry L 1993. Moral fragments and moral community. Philadelphia: Fortress Press.

Tutu, Desmond 2005. God has a Dream: A Vision of Hope for our Time. New York: Double Day.

Van der Borght, Eddy 2009. "Sunday morning the most segregated hour: On racial reconciliation as unfinished business for theology in South Africa and beyond". Inaugural lecture deliverd upon accepting the position of VU University Amsterdam Desmond Tutu chair. 